Volume 16 (2) (2020) : 231-252
Jurnal Borne0 Administrator
p-issn : 1858-0300; e-issn : 2407-6767
http://samarinda.lan.go.id/jba
DOl : 10.24258/jba.v16i2.651

\title{
PENGARUH KEMAMPUAN MENYUSUN PERENCANAAN DAN MEMOBILISASI STAKEHOLDER TERHADAP PENCAPAIAN TARGET KINERJA PEJABAT PUBLIK DI INDONESIA
}

\section{THE INFLUENCE OF PLANNING ABILITY AND MOBILIZING STAKEHOLDER ON ACHIEVEMENT OF PUBLIC OFFICIALS PERFORMANCE TARGETS IN INDONESIA}

\author{
Putri Wulandari Atur Rejeki dan Yuyu Yuningsih \\ Pusat Pelatihan dan Pengembangan dan Pemetaan Kompetensi Aparatur Sipil \\ Negara, Lembaga Administrasi Negara (Puslatbang PKASN LAN) \\ Jl. Kiarapayung Km 4,7 Jatinangor Sumedang, \\ Email: putriwulandari37@gmail.com; yuyu.yuningsih310@gmail.com
}

Naskah diterima: 20 Februari 2020; revisi terakhir: 6 Agustus 2020; disetujui 13 Agustus 2020

How to Cite: Rejeki, Putri W.A., dan Yuningsih, Yuyu. (2020). Pengaruh Kemampuan Menyusun Perencanaan dan Memobilisasi Stakeholder terhadap Pencapaian Target Kinerja Pejabat Publik di Indonesia. Jurnal Borneo Administrator, 16 (2), 231-252. https://doi.org/10.24258/iba.v16i2.651

\begin{abstract}
Public officials as leaders who take care of the interests of many people are bound to have managerial abilities such as planning ability and mobilizing stakeholder ability to achieve organizational goals. This research aims to discover the influence of the ability to formulate plans and mobilize stakeholder in achieving performance targets for public officials in Indonesia. This research used a quantitative approach. The population was all public officials in Indonesia. The sample used was all participants of the Leadership Training in Puslatbang PKASN LAN in 2019. Multiple linear analysis was used to analyze the data. The dependent variable was Performance Target Achievement of Public Officials (PTKPP). The independent variable was Ability to Plan (KMP) and Ability to Mobilize Stakeholder (KMS). The results showed that the $R^{2}$ value was 0.878 . It means that $87.8 \%$ of the public official performance targets could be explained by planning and mobilizing stakeholder ability. It also showed that both variables had a positive and significant influence on the achievement of public officials' performance targets. Further research needs to be conducted to measure and modelize various aspects related to the achievement of public officials' performance targets beside two variables used in this research, such as human resources, budget, and facilities.
\end{abstract}

Keywords: Public Officials, Planning, Mobilizing, Stakeholder, Performance

\begin{abstract}
Abstrak
Pejabat publik sebagai seorang pemimpin yang mengurusi kepentingan orang banyak dituntut untuk memiliki kemampuan manajerial, seperti kemampuan menyusun
\end{abstract}


perencanaan dan kemampuan memobilisasi stakeholder dalam rangka pencapaian target kinerjanya. Tujuan penelitian ini adalah untuk mengetahui bagaimana pengaruh kemampuan menyusun perencanaan dan memobilisasi stakeholder terhadap pencapaian target kinerja pejabat publik di Indonesia. Penelitian ini menggunakan pendekatan kuantitatif. Populasi dalam penelitian ini adalah seluruh pejabat publik di Indonesia. Sampel yang digunakan adalah seluruh peserta Pelatihan Kepemimpinan di Puslatbang PKASN LAN pada tahun 2019. Teknik analisis yang digunakan adalah analisis regresi linier berganda. Variabel dependen dalam penelitian ini adalah Pencapaian Target Kinerja Pejabat Publik (PTKPP). Variabel independen adalah Kemampuan Membuat Perencanaan (KMP) dan Kemampuan Memobilisasi Stakeholder (KMS). Hasil penelitian menunjukkan bahwa nilai determinasi $\left(R^{2}\right)$ sebesar 0,878 yang berarti bahwa sebesar $87,8 \%$ variasi pencapaian target kinerja pejabat publik di Indonesia dapat dijelaskan oleh kemampuan menyusun perencanaan dan kemampuan memobilisasi stakeholder. Hasil penelitian juga menunjukkan bahwa kedua variabel tersebut memiliki pengaruh positif dan siginifikan terhadap pencapaian target kinerja pejabat publik. Penelitian lanjutan perlu dilakukan dengan menambahkan beberapa variabel independen yang berkaitan dengan pencapaian target kinerja pejabat publik, seperti dukungan sumber daya manusia, anggaran, dan sarana dan prasarana.

Kata kunci: Pejabat Publik, Perencanaan, Mobilisasi, Stakeholder, Kinerja

\section{A. PENDAHULUAN}

Pejabat publik adalah pegawai pemerintah yang memegang jabatan penting sebagai pimpinan yang mengurusi kepentingan masyarakat. Seorang pejabat publik dapat menduduki jabatan pada instansi pemerintah maupun nonpemerintah. Pejabat publik menggunakan, baik Anggaran Pendapatan dan Belanja Negara (APBN) maupun Anggaran Pendapatan dan Belanja Daerah (APBD) dalam menjalankan organisasi sebagai bentuk kinerjanya. Pejabat publik bukan hanya presiden, gubernur dan pejabat-pejabat yang berada di level atas saja, pejabat struktural yang memimpin unit di level terendah pun disebut sebagai pejabat publik (Nugroho, 2008:64).

Dalam upayanya mencapai target kinerja, seorang pemimpin, dalam hal ini pejabat publik, harus memiliki kemampuan membuat perencanaan dan dapat mengorganisasikan sumber daya yang dimiliki (Peramesti \& Kusmana, 2018:73). Proses penyusunan rencana kinerja yang diejawantahkan dalam bentuk sasaran kegiatan dan program kegiatan yang telah ditetapkan disebut sebagai perencanaan kinerja. Sasaran dan program ini biasanya didokumentasikan dalam rencana strategis (Renstra) instansi. Kegiatan tahunan instansi merupakan wujud dari perencanaan kinerja instansi pemerintah (Fairus \& Andri, 2014: 98). Perencanaan yang telah dibuat tersebut seringkali mengalami perubahan dalam implementasinya. Pemimpin, dengan segala kompetensi yang dimilikinya, berperan dalam menghadapi perubahan tersebut (Battilana et al., 2010: 423). Pejabat publik dituntut untuk dapat menyusun perencanaan yang efektif dan dapat mengatasi permasalahan yang muncul pada saat rencana tersebut diimplementasikan.

Pejabat publik di semua level organisasi tentunya tidak bekerja sendirian. Proses kolaborarasi tentunya diperlukan dan stakeholder terkait dibutuhkan untuk mencapai tujuan. Stakeholder bisa berasal dari internal organisasi (anak buah, atasan, rekan sejawat, dan lainlain) ataupun eksternal organisasi (pengguna layanan, masyarakat, dan lain-lain). Seorang pejabat publik memerlukan kemampuan memobilisasi stakeholder yang kuat agar mendapatkan dukungan dalam merealisasikan apa yang telah direncanakan sebelumnya (Asmoko, 2014: 1-19). 
Kemampuan pejabat publik diuji dalam memobilisasi stakeholder guna menyediakan tenaga kerja dan kontraktor lokal dalam program penataan lingkungan berbasis komunitas (Nurhidayah, 2018: 12-18). Seorang pemimpin perlu membentuk jaringan (networking) dan membentuk hubungan dengan individu yang berkuasa dan dihormati agar tujuan organisasi dapat dicapai (Northouse, 2016: 367-382). Mereka juga harus memiliki kemampuan memengaruhi orang lain, memengaruhi aktivitas suatu kumpulan atau golongan kemudian mengarahkannya dalam rangka mencapai tujuan. Yudiatmaja (2013: 29-38) dan McCarthy dan Zald dalam Sari (2017: 127-134) menjelaskan betapa pentingnya kemampuan memobilisasi sumber daya dengan dasar support/sokongan, strategi dan pendekatan, serta hubungan dengan masyarakat. Kemampuan memobilisasi sumber daya salah satunya meliputi identifikasi sumber daya dan usaha apa yang digunakan oleh pihak berwenang untuk mengelola sumber daya tersebut. Pejabat publik yang memiliki kecerdasan emosional dapat bekerja secara harmonis dalam membangun hubungan dengan stakeholder (Boyatzis \& McKee, 2006:5).

Kemampuan memimpin seorang pejabat publik, salah satunya dapat dilihat dari kemampuannya memimpin suatu rencana/proyek perubahan di unit kerjanya. Terdapat dua aspek penting dalam memimpin sebuah rencana/proyek perubahan tersebut. Pertama, menentukan area dan fokus perubahan dalam proses perencanaan. Kedua, keterampilan memengaruhi dan memobilisasi stakeholder yang dapat mendukung dalam proses implementasi proyek perubahan tersebut (Syukur, 2014: 1-10). Kedua hal tersebut dilakukan oleh para peserta pelatihan kepemimpinan, sebagai pejabat publik, yang menjadi obyek penelitian ini.

Berdasarkan penjelasan tersebut, kemampuan menyusun perencanaan ataupun kemampuan memobilisasi stakeholder, baik secara parsial maupun bersama-sama berpengaruh terhadap pencapaian tujuan (target kinerja) pejabat publik. Dengan memperhatikan prinsip kebaruan dalam penelitian (novelty), penelitian ini dilakukan untuk mengetahui pengaruh antara kemampuan menyusun perencanaan dan kemampuan memobilisasi stakeholder terhadap pencapaian target kinerja pejabat publik.

\section{B. METODE PENELITIAN}

Sebagai perwujudan dari pejabat publik, peserta Pendidikan dan Pelatihan Kepemimpinan (Diklatpim) yang sekarang dikenal dengan istilah Pelatihan Kepemimpinan diajarkan agar memiliki berbagai kompetensi kepemimpinan seperti menyusun perencanaan dan memobilisasi stakeholder yang berguna dalam pencapaian target kinerja organisasi.

Populasi penelitian ini adalah pejabat publik di Indonesia yang telah mengikuti Pelatihan Kepemimpinan. Metode sampling dalam penelitian ini adalah purposive sampling method dengan kriteria sampel adalah pejabat publik yang menjadi peserta pelatihan kepemimpinan yang terdiri dari Pelatihan Kepemimpinan Nasional Tingkat II (PKN Tk. II), Pendidikan dan Pelatihan Kepemimpinan Tingkat III (Diklatpim Tk. III), dan Pendidikan dan Pelatihan Kepemimpinan Tingkat IV (Diklatpim Tk. IV) yang diselenggarakan oleh Pusat Pelatihan dan Pengembangan dan Pemetaan Kompetensi Aparatur Sipil Negara Lembaga Administrasi Negara Republik Indonesia (Puslatbang PKASN LAN RI) pada tahun 2019. Pejabat publik yang menjadi peserta pelatihan ini merupakan pejabat publik yang berasal dari berbagai instansi pusat dan daerah di Indonesia.

Tujuan penelitian, yaitu untuk mendapatkan bukti empiris mengenai pengaruh kemampuan menyusun perencanaan dan kemampuan memobilisasi stakeholder terhadap pencapaian target kinerja pejabat publik di Indonesia. Desain penelitian yang digunakan, 
yaitu dengan melakukan pengujian asumsi-asumsi model regresi yang digunakan dan menentukan pengaruh antara variabel independen terhadap variabel dependen.

Variabel independen dalam penelitian ini adalah variabel kemampuan menyusun perencanaan dan variabel kemampuan memobilisasi stakeholder sedangkan variabel dependennya yaitu variabel pencapaian target kinerja pejabat publik. Variabel kemampuan menyusun perencanaan diproksi melalui penilaian proyek perubahan peserta pelatihan kepemimpinan. Kemampuan menyusun perencanaan lebih dikhususkan dalam pembuatan proyek inovasi sebagai tahap akhir dalam pelaksanaan pelatihan. Adapun indikator penilaian untuk komponen ini, yaitu jenis perubahan, cakupan manfaat perubahan, kejelasan tahap perubahan, dan peta pemangku perubahan.

Variabel kemampuan memobilisasi stakeholder diproksi melalui penilaian dalam komponen manajemen perubahan peserta pelatihan kepemimpinan. Variabel ini dilihat dari jumlah kegiatan yang dilakukan dalam rangka sosialisasi dan penguatan dukungan pada saat pelaksanaan laboratorium kepemimpinan disertai bukti yang jelas (notulen/transkrip tertulis/audio/visual, output hasil mobilisasi, foto, daftar hadir, dan lain-lain). Variabel dependen pada penelitian ini yaitu pencapaian target kinerja pejabat publik yang merupakan capaian tahap perubahan yang dilakukan oleh peserta pelatihan kepemimpinan.

Penelitian ini menggunakan data sekunder yang diperoleh dari hasil seminar Rancangan Proyek Perubahan (Seminar RPP) dan seminar Laporan Proyek Perubahan (Seminar LPP) yang diikuti oleh peserta pelatihan kepemimpinan. Data yang dimaksud meliputi (1) nilai kemampuan menyusun perencanaan yang diproksi dengan nilai seminar Rancangan Proyek Perubahan; (2) nilai kemampuan memobilisasi stakeholder yang diproksi dengan nilai kegiatan memobilisasi stakeholder pada seminar Laporan Proyek Perubahan; dan (3) nilai pencapaian target kinerja pejabat publik yang diproksi dengan nilai capaian tahap perubahan pada seminar Laporan Proyek Perubahan. Ketiga data tersebut merupakan data cross section berskala interval.

Adapun hipotesis penelitian ini adalah:

H1 : Kemampuan menyusun perencanaan dan kemampuan memobilisasi stakeholder secara bersama-sama berpengaruh positif dan signifikan terhadap pencapaian target kinerja pejabat publik.

Pengujian hipotesis dilakukan untuk mengetahui ada atau tidaknya pengaruh antara variabel independen terhadap variabel dependen melalui analisis tingkat signifikansi koefisien regresi dari variabel independen. Tingkat signifikansi untuk tiap-tiap variabel independen bergantung pada nilai t statistik dari data yang diperoleh. Teknik pengujian hipotesis dilakukan dengan analisis regresi linier berganda (Multi-Linear Regression). Sebelumnya, pengujian asumsi klasik dilakukan melalui uji normalitas, heteroskedastisitas, multikolinieritas, dan autokorelasi. Uji autokorelasi tidak diperlukan karena data penelitian termasuk ke dalam data cross section (Janie, 2012:13).

Vining dan Walpole dalam Farizal, Rachman, \& Al Rasyid (2014: 166-176) mempresentasikan model regresi linier berganda dengan persamaan umum sebagai berikut:

$$
\mathrm{Y}=\mathrm{a}+\mathrm{b} i \mathrm{X} i+e
$$

Model regresi linier berganda yang digunakan pada penelitian ini menggunakan dua tipe variabel. Pertama, variabel dependen, yaitu variabel Pencapaian Target Kinerja Pejabat 
Publik (PTKPP). Kedua, variabel independen, yaitu variabel Kemampuan Menyusun Perencanaan (KMP) dan variabel Kemampuan Memobilisasi Stakeholder (KMS). Model regresi berganda pada penelitian ini adalah:

$$
\mathrm{PTKPP}=\alpha+\beta_{1} \mathrm{KMP}+\beta_{2} \mathrm{KMS}+\varepsilon
$$

Keterangan:

$\begin{array}{ll}\text { PTKPP } & =\text { Pencapaian Target Kinerja Pejabat Publik sebagai variabel dependen } \\ \text { KMP } & =\text { Kemampuan Menyusun Perencanaan sebagai variabel independen } \\ \text { KMS } & =\text { Kemampuan Memobilisasi Stakeholder sebagai variabel independen } \\ \alpha & =\text { konstanta } \\ \beta_{1} & =\text { koefisien regresi variabel KMP } \\ \beta_{2} & =\text { koefisien regresi variabel KMS }\end{array}$

\section{KERANGKA TEORI}

\section{Pejabat Publik}

Pejabat publik diartikan sebagai pegawai pemerintah yang memegang jabatan penting sebagai pimpinan yang mengurusi kepentingan orang banyak. Pejabat publik juga diartikan sebagai orang yang ditunjuk dan diberi tugas untuk menduduki posisi atau jabatan tertentu pada badan publik. Badan publik terdiri dari lembaga eksekutif, legislatif, yudikatif, dan badan lain yang tugas pokok dan fungsinya berhubungan dengan penyelenggaraan negara/pemerintah. Badan publik menggunakan anggaran pemerintah pusat dan/atau pemerintah daerah, atau organisasi nonpemerintah yang sebagian/seluruh dananya dari anggaran pemerintah pusat dan/atau pemerintah daerah, sumbangan masyarakat dan/atau luar negeri.

Pejabat publik memiliki tugas pokok, fungsi dan tanggung jawab sebagai seorang pemimpin yang memiliki visi, misi dan tujuan sesuai organisasi/instansi yang dipimpinnya. Pejabat publik harus mampu mengelola sumber daya yang dikuasainya dalam rangka pencapaian tujuan bersama. Pejabat publik digolongkan menjadi dua kelompok besar, yaitu Pejabat Negara dan Pejabat Administratif. Pejabat Negara terdiri atas lima kelompok. Pertama, yaitu pejabat legislatif yang terdiri atas Ketua, Wakil Ketua, dan Anggota Majelis Permusyawaratan Rakyat (MPR), Dewan Perwakilan Rakyat (DPR), Dewan Perwakilan Rakyat Daerah (DPRD), dan Dewan Perwakilan Daerah (DPD); kedua, yaitu pejabat yudikatif yang terdiri dari Pimpinan Mahkamah Agung (MA), Mahkamah Konstitusi (MK) dan Komisi Yudisial (KY); ketiga, yaitu pejabat eksekutif, terdiri atas Presiden dan Wakil Presiden, Menteri dan pejabat pemerintah setingkat menteri, gubernur dan wakil gubernur, duta besar, bupati dan wakil bupati serta walikota dan wakil walikota; keempat, yaitu pejabat akuntatif, yakni pimpinan Badan Pemeriksa Keuangan (BPK); dan kelima yaitu pejabat lembaga publik semi-negara yang terdiri dari Komisi Pemberantasan Korupsi (KPK), Komisi Nasional Hak Asasi Manusia (KomnasHAM), Komisi Pengawas Persaingan Usaha (KPPU) dan badan-badan regulator infrastruktur publik, seperti Badan Pengatur Jalan Tol (BPJT), Badan Pembinaan Hukum Nasional (BPHN) dan lain-lain. Selain pejabat negara, pejabat administratif juga termasuk ke dalam pejabat publik. Pejabat administratif terdiri dari empat kelompok, yaitu pertama, pejabat struktural pusat; kedua, pejabat struktural daerah provinsi; ketiga, yaitu pejabat struktural daerah 
kabupaten/kotamadya; dan keempat, yaitu pejabat pimpinan pelaksana di tingkat bawah seperti camat, kepala desa/lurah (Nugroho, 2008:64).

Pejabat publik dituntut untuk memiliki kepemimpinan yang efektif dalam upayanya mencapai visi, misi, dan tujuan organisasi. Kepemimpinan yang efektif salah satunya melibatkan kompetensi manajerial yang dimiliki oleh seorang pemimpin. Salah satu kompetensi manajerial yang dimaksud, yaitu kemampuan menyusun perencanaan dan mengelola sumber daya organisasi, termasuk kemampuan dalam memobilisasi stakeholder. Hal ini tentunya didukung oleh budaya organisasi, tim yang efektif, dan peran serta stakeholder dalam mencapai tujuan bersama.

\section{Teori Kepemimpinan}

Pada tahun 1900-1929, kepemimpinan diartikan sebagai kemampuan menjadikan orang lain melakukan apa yang pemimpin inginkan, biasanya melalui kekuasaan dan dominasi, ditunjukan dengan istilah Directive Leadership dan Transactional Leadership. Pada tahun 1930-an, kepemimpinan diartikan sebagai pengaruh, bukan dominasi, difasilitasi oleh cici-ciri kepribadian pemimpin yang sesuai dengan kelompoknya. Kepemimpinan sebagai "Pelibatan Kelompok" mendominasi pada tahun 1940—1960 dengan munculnya "bujuk rayu" sebagai taktik/strategi yang mendefinisikan tujuan bersama dan kepemimpinan merupakan efektifitas kelompok. Tahun 1970-an, arti kepemimpinan bergeser dari fokus terhadap kelompok menjadi fokus terhadap organisasi dan kepemimpinan menjadi proses timbal balik, yaitu motif dan nilai seseorang dimobilisasi seiring dengan sumber daya untuk mencapai tujuan bersama. Teori kepemimpinan berkembang pada tahun 1980-an dengan munculnya varian baru, yaitu pemimpin sebagai transformasi atau dikenal dengan istilah Transformational/Charismatic Leadership yang menekankan bahwa pemimpin dan anggota kelompoknya terlibat bersama dalam mewujudkan prestasi yang tinggi (Johnson, 2018: 160).

Teori kepemimpinan telah berevolusi dari teori orang hebat menjadi teori kepemimpinan transformasional. Menurut teori orang hebat, seorang pemimpin merupakan orang-orang luar biasa yang memiliki sifat-sifat tertentu dan kualitas yang luar biasa dan dilahirkan untuk menjadi pemimpin. Teori kepemimpinan situasional menyatakan bahwa gaya kepemimpinan harus disesuaikan dengan situasi yang dihadapi, seperti directive leadership mungkin sesuai untuk lingkungan yang sangat repetitif dan mekanistik sedangkan gaya partisipatif/transformasional leadership akan lebih cocok untuk lingkungan yang dinamis (Johnson, 2018: 160) . Lebih lanjut, teori kepemimpinan karismatik menyebutkan bahwa pemimpin adalah mereka yang dapat membuat perubahan dan pengaruh melalui pendekatan yang inkonvensional dan inovatif (Fahmi, Prawira, Hudalah, \& Firman, 2015: 1-22).

Pengertian umum tentang kepemimpinan adalah seseorang yang, baik dengan perkataan maupun contoh perbuatan, dapat memberikan pengaruh secara nyata terhadap perbuatan, pemikiran dan/atau perasaan sejumlah orang secara signifikan. Beralih ke abad ke-21, kepemimpinan didefinisikan sebagai proses yang terdiri dari beberapa bagian. Beberapa bagian dari proses ini, yaitu Authentic Leadership (transparan dan menggunakan perilaku etis seseorang sebagai contoh); Servant Leadership (memperhatikan kebutuhan pengikut); dan Adaptive/Empowering Leadership (menekankan pada pembelajaran dan pengembangan diri). Saat ini kepemimpinan diartikan lebih luas lagi, yaitu sebagai perwujudan yang berfokus kepada visi, tantangan, kolaborasi, proses dan produk. Pengertian kepemimpinan telah berevolusi seiring waktu dan saat ini menjadi 
berorientasikan pada proses termasuk dalam kemampuan berorganisasi ataupun kemampuan sosial (Johnson, 2018: 160).

Teori kepemimpinan terus berkembang seiring dengan perubahan lingkungan sosial kultural, ekonomi dan politik. Vicki Squires mendefinisikan kepemimpinan sebagai sebuah proses dimana seseorang memengaruhi sekumpulan orang untuk mencapai tujuan bersama (Squires, 2018: 91-94). Hubungan antara pemimpin dan pengikutnya merupakan elemen penting agar proses kepemimpinan berjalan. Sebagai sebuah proses, maka seorang pemimpin tidak terbatas pada pemimpin formal yang telah ditentukan dalam suatu kelompok namun setiap orang dapat menjadi seorang pemimpin. Para pemimpin tidak berada di atas atau lebih baik dari para pengikutnya, tetapi mereka harus memahami hubungan satu sama lain yang diibaratkan dua sisi dalam satu koin. Kepemimpinan merupakan proses yang mirip dengan manajemen dimana sama-sama melibatkan pengaruh, kerja sama dan pencapaian tujuan bersama. Walaupun seringkali terjadi tumpang tindih antara proses manajemen dan proses kepemimpinan, tetapi terdapat perbedaan, yaitu dalam manajemen berfokus pada penyediaan urutan/tata tertib dan konsistensi bagi organisasi, sedangkan fungsi utama kepemimpinan, yaitu menghasilkan perubahan dan mobilitas. Manajemen mengenai pencarian stabilitas namun kepemimpinan mengenai pencarian perubahan yang adaptif dan konstruktif (Squires, 2018: 91-94).

Dalam menjalankan proses kepemimpinan, para pemimpin memiliki dampak terhadap para pengikutnya/anggota kelompoknya. Para pemimpin biasanya memiliki kekuasaan dan kendali lebih dibandingkan anggota kelompoknya sehingga mereka juga memiliki tanggung jawab lebih untuk menjadi sensitif akan bagaimana kepemimpinannya memengaruhi kehidupan anggotanya. Oleh karenanya, pemimpin harus memiliki etika kepemimpinan. Terdapat lima prinsip dari kepemimpinan yang beretika, yaitu menghormati orang lain, melayani orang lain, menegakkan keadilan menunjukan kejujuran, dan membangun komunitas (Northouse, 2016: 341).

Teori kepemimpinan berkembang melalui berbagai jenis pendekatan, di antaranya pendekatan kepribadian, pendekatan keterampilan, pendekatan perilaku dan pendekatan situasional. Menurut teori kepemimpinan dengan pendekatan kepribadian, jika seseorang ingin dianggap sebagai pemimpin oleh orang lain, ia harus memiliki kepribadian meliputi di antaranya intelegensi, kepercayaan diri, determinasi, integritas, dan kemampuan sosial. Menurut teori kepemimpinan dengan pendekatan keterampilan, seorang pemimpin harus memiliki keterampilan teknis, keterampilan tentang manusia dan keterampilan mengenai konsep yang berbeda-beda berkaitan dengan posisi pemimpin dalam level manajemen yang terdiri dari top management, middle management dan supervisory management. Top management dituntut memiliki keterampilan konsep dan keterampilan manusia yang lebih tinggi dibandingkan level manajemen yang lain. Middle management dituntut untuk memiliki ketiga keterampilan tersebut dengan porsi yang sama sedangkan level supervisory management dituntut untuk memiliki keterampilan teknis dan manusia yang lebih banyak dibandingkan dengan keterampilan konsep (Northouse, 2016: 46).

Kepemimpinan adalah kemampuan menginspirasi orang lain untuk mengikutinya dan mengubah masa depan. Kemampuan dasar seorang pemimpin terdiri atas integritas, visi, keberanian, dan kesetiaan terhadap prinsip. Seorang pemimpin harus menunjukkan perhatian tulus, menjadi teladan dalam hal kerja keras dan kerendahan hati, mudah ditemui, murah hati, mendelegasikan, tetapi tetap mensupervisi. Seorang pemimpin bertanggung jawab atas kegagalan yang dialami dan dapat berbagi pengakuan atas keberhasilan (Margulis, 2002:1). 
Kepemimpinan tentunya merupakan kondisi aktif, bukan pasif. Kepemimpinan merupakan hasil dari hubungan yang aktif antara pemimpin dan para anggota kelompoknya. Karakteristik seorang pemimpin tersebut di antaranya, yaitu mendorong rasa tanggung jawab dan penyelesaian tugas, bersemangat dan gigih dalam mengejar tujuan, berani mengambil risiko, memiliki orisinalitas, mendorong perilaku inisiatif dalam situasi dan kondisi sosial, memiliki kepercayaan diri dan rasa identitas pribadi, bersedia menerima akibat dari setiap keputusan dan perbuatan, memiliki kesiapan untuk menerima stres interpersonal, bersedia mentolerir frustrasi dan keterlambatan, mampu untuk memengaruhi sikap dan perilaku orang lain, serta memiliki kapasitas untuk menyusun sistem interaksi sosial. Semuanya itu dilakukan dengan tetap memperhatikan tujuan yang telah ditetapkan (Northouse, 2016: 21).

Seorang pemimpin harus memiliki keserasian dengan orang-orang yang di sekitarnya sehingga kerja sama akan terjalin secara harmonis, selaras dan dapat terhubung dengan pemikiran dan emosi orang lain. Hal ini dapat terwujud melalui pemimpin yang memiliki kecerdasan emosional sehingga ia mampu mengelola emosi orang lain, dapat membangun hubungan yang kokoh dan dapat dipercaya (Boyatzis \& McKee, 2006:5). Selain memiliki kecerdasan emosional, seorang pemimpin harus memiliki kemampuan menciptakan tim yang efektif. Tim yang efektif diharapkan akan mencapai hal-hal yang diharapkan seperti produktifitas yang lebih tinggi, penggunaan sumber daya yang lebih efektif, pengambilan keputusan yang lebih baik, pemecahan masalah yang lebih baik, produk dan layanan yang lebih berkualitas, dan kreatifitas dan inovasi yang lebih besar. Budaya organisasi yang mendukung keterlibatan anggota tim dalam pengambilan keputusan juga mendukung keberhasilan tim. Tim akan mengalami kesulitan dalam budaya organisasi yang tidak mendukung kolaborasi dan pengambilan keputusan di level bawah (Northouse, 2016: 367382).

Salah satu model tentang efektifitas tim dinamakan The Hill Model yang merupakan kerangka konseptual untuk membantu pemimpin dalam membuat keputusan, tetapi keterampilan tambahan mungkin diperlukan tergantung tipe tim yang dimiliki dan situasi yang dihadapi. Berdasarkan model tersebut, terdapat serangkaian keterampilan dan/atau tindakan yang harus dilakukan oleh pemimpin untuk meningkatkan kinerja. Seorang pemimpin harus mampu mengambil keputusan, baik internal maupun eksternal. Salah satu tindakan kepemimpinan internal, yaitu menyusun rencana demi hasil yang diwujudkan dalam bentuk perencanaan, visioning, pengelolaan sumber daya serta pembagian tugas dan peran yang jelas. Dalam hal tindakan kepemimpinan eksternal, seorang pemimpin perlu membentuk jaringan dan sekutu dengan cara berinteraksi dan membentuk hubungan dengan individu yang berkuasa dan dihormati. Faktor terpenting dalam kesuksesan tim adalah proses kepemimpinan yang efektif. Tim yang efektif dapat mencapai dua tujuan utama, yaitu menyelesaikan tugas dan mempertahankan tim yang kompak (Northouse, 2016: 367382).

Pejabat publik, sebagai seorang pemimpin, memiliki area yang sangat luas, tidak hanya berkaitan dengan lingkungan publik, nilai-nilai publik, tetapi juga berkaitan dengan menyediakan pemikiran yang sangat relevan terhadap teori kepemimpinan pada umumnya. Definisi kepemimpinan publik yaitu berubah, yakni mencerminkan perubahan dalam masyarakat dan peran berbagai grup dan institusi dalam kondisi pemerintahan yang polisentris. Terdapat sepuluh dalil kepemimpinan publik yang harus diteliti lebih dalam lagi, yaitu (1) perbedaan antara kepemimpinan publik dan kepemimpinan pelayanan publik; (2) pertimbangan konteks kepemimpinan yang sangat dinamis; (3) kejelasan tujuan dalam kepemimpinan; (4) konflik dan perlawanan yang terletak di inti kepemimpinan publik; (5) 
kepemimpinan membutuhkan kecerdikan politis; (6) nilai pemikiran tentang kepemimpinan ganda; (7) kepemimpinan dapat mencakup proyeksi dari orang lain; (8) perlunya menumbuhkan ketangguhan pribadi pada para pemimpin publik; (9) kepemimpinan, otoritas dan legitimasi; serta (10) desain dan metode penelitian untuk mencerminkan kompleksitas dan dinamika (Hartley, 2018: 202-217).

Dalil-dalil kepemimpinan publik mewakili beberapa tema mendasar, yakni perubahan konteks yang berhubungan dengan berbagai stakeholder, meluasnya konflik, kebutuhan untuk berfikir dan bertindak baik secara politis maupun secara prosedur hukum dan organisasi, pluralitas kepemimpinan dan minat publik. Tingkat volatilitas yang tinggi, ketidakpastian, hilangnya kepercayaan dan arahan di masyarakat menjadi pengingat bahwa kepemimpinan publik diperlukan (Hartley, 2018: 202-217).

\section{Kemampuan Merencanakan dan Memobilisasi Stakeholder}

Proses penyusunan rencana kinerja yang diejawantahkan dalam bentuk sasaran kegiatan dan program kegiatan yang telah ditetapkan disebut sebagai perencanaan kinerja. Sasaran dan program ini biasanya didokumentasikan dalam rencana strategis (renstra) instansi. Kegiatan tahunan instansi merupakan wujud dari perencanaan kinerja instansi pemerintah (Fairus \& Andri, 2014: 98). Seorang pemimpin harus merencanakan strategi apa yang akan dilaksanakan dalam mencapai tujuan. Perencanaan strategi yang dibuat seringkali mengalami perubahan dalam implementasinya. Perubahan dalam perencanaan seringkali berkaitan dengan perubahan struktur, desain dan kontrol dalam organisasi serta bagaimana menetapkan rutinitas untuk mencapai tujuan tersebut. Pemimpin, dengan segala kompetensi yang dimilikinya, berperan dalam menghadapi perubahan tersebut (Battilana et al., 2010: $\underline{423})$.

Kemampuan menyusun perencanaan juga disebutkan sebagai salah satu keterampilan kognitif yang harus dimiliki oleh pemimpin dalam rangka meningkatkan kinerja. Keterampilan kognitif lainnya yaitu kemampuan mendefinisikan masalah, melakukan analisis cause/goal, melakukan analisis hambatan, berfikir kreatif, kemampuan melakukan forecasting, mengevaluasi ide, memiliki kebijaksanaan dan membuat visi (Mumford, Todd, Higgs, \& McIntosh, 2016: 1-16). Selain keterampilan kognitif, seorang pemimpin juga harus memiliki keterampilan interpersonal, diantaranya yaitu memiliki perilaku yang mendorong interaksi kolaboratif antaranggota organisasi, membangun iklim sosial yang mendukung dan mempromosikan praktik manajemen yang memastikan perlakuan yang adil di antara anggota organisasi. Dalam menghadapi perubahan, seorang pemimpin harus fokus pada tiga aktivitas kunci, yaitu komunikasi, mobilisasi, dan evaluasi (Battilana et al., 2010:424).

Berkaitan dengan komunikasi, seorang pemimpin harus mengomunikasikan kebutuhan akan perubahan kepada para anggotanya agar terdapat pemahaman yang sama mengapa perilaku dan rutinitas perlu untuk berubah. Selama implementasi perencanaan, pemimpin harus memobilisasi anggota organisasi untuk menerima dan mengadopsi perubahan ke dalam tugas sehari-hari. Tujuan memobilisasi adalah untuk mengembangkan kapasitas organisasi agar berkomitmen dan bekerja sama dengan serangkaian kegiatan yang telah direncanakan. Pemimpin harus menciptakan koalisi untuk mendukung proyek perubahan. Menciptakan koaliasi semacam ini merupakan proses politik yang mengharuskan kerja sama anggota organisasi dan menginisiasi proses dan sistem organisasi yang memungkinkan terjadinya kerja sama tersebut. Dengan fokus pada pencapaian tujuan, pemimpin harus mengidentifikasi para stakeholder yang perlu dilibatkan terkait proyek perubahan dan membangun sistem yang memfasilitasi keterlibatan mereka dalam rangka membangun koalisi (Battilana et al., 2010:424). 
Berkaitan dengan mobilisasi, peran penting seorang pemimpin sebagai pejabat publik adalah dalam hal penyampaian informasi kepada orang yang lebih berwenang. Pengendalian atas informasi akan memberikan kekuasaan kepada stakeholder dalam pengambilan keputusan. Keterampilan memobilisasi stakeholder merupakan keterampilan antarpribadi (interpersonal) yang perlu dikembangkan oleh seorang pemimpin. Makin tinggi tingkat pekerjaan seseorang, makin tinggi pula jumlah dan keragamaan kegiatan yang harus dikoordinasikan. Makin tinggi tingkat kerumitan hubungan yang harus dipahami dan dikelola, maka akan makin spesial dan makin berat masalah yang harus dipecahkan, sehingga mendorong keterampilan untuk membangun hubungan yang lebih kuat dengan pihak-pihak yang dianggap dapat membantu dalam pencapaian kinerja (Yukl, 2009: 241).

Pemimpin biasanya melakukan beberapa metode dalam mencapai tujuan, di antaranya, yaitu melalui perintah, koordinasi, kerja sama, dan kolaborasi. Menurut Shergold O'Flynn \& Wanna (2016: 20) perintah diartikan sebagai proses kontrol terpusat dengan jalur kekuasaan/kewenangan hierarki yang jelas. Koordinasi diartikan sebagai proses pengambilan keputusan yang dilakukan secara kolektif, berkenaan dengan institusi terkait. Kerjasama diartikan sebagai proses berbagi ide/gagasan dan sumber daya untuk kepentingan bersama. Kolaborasi memiliki dimensi yang berbeda dengan perintah, koordinasi maupun kerja sama. Kolaborasi melibatkan kerja sama untuk membangun kesamaan, meningkatkan konsistensi dan keselarasan, mengembangkan motivasi serta melibatkan peran pengawasan dan pemeriksaan. Kolaborasi dapat berupa proses negosiasi dan berkompromi, serta dapat melibatkan kekuatan dan paksaan sampai batas tertentu (O’Flynn \& Wanna, 2016:3-20).

Pergeseran paradigma manajemen publik memunculkan istilah collaborative governance. Collaborative governance diartikan sebagai suatu proses kerja sama yang dilakukan oleh lembaga publik dengan pihak-pihak terkait, baik langsung maupun tidak langsung untuk memecahkan masalah publik dan mencapai tujuan bersama yang tidak dapat dicapai melalui satu pihak saja. Bentuk kerja sama yang dilakukan dapat berupa proses pembuatan dan/atau pelaksanaan peraturan/kebijakan, atau mengelola program. Biasanya bersifat formal, berorientasi kesepakatan dan deliberatif. Kerja sama ini dapat dilakukan, baik antara instansi pemerintah, sektor swasta, masyarakat, komunitas, maupun pemerintah gabungan dan pengaturan hybrid, seperti kemitraan publik-swasta dan swasta-sosial (Ansell \& Gash, 2008:544; Arrozaaq, 2016:6; Emerson, Nabatchi, \& Balogh, 2012:3; Febrian, 2016:202; Harmawan, Wasiati, \& Rohman, 2017:51; Tilano \& Suwitri, 2019:6). Dengan kata lain, collaborative governance merupakan proses kerja sama/pelibatan stakeholder terkait dalam proses pengambilan keputusan atau penyelesaian masalah yang dihadapi publik. Pengambilan keputusan ini biasanya dilakukan oleh seorang pemimpin, atau dalam konteks penelitian ini, yaitu pejabat publik.

Seorang pejabat publik harus mampu memobilisasi stakeholder dalam mendukung program/kegiatan yang sudah direncanakan dalam rangka pencapaian tujuan yang telah ditetapkan. Mobilisasi merupakan proses mengelola dan/atau mempersiapkan sesuatu, contohnya sekelompok orang untuk mencapai suatu tujuan. Kepemimpinan dapat digambarkan sebagai proses dimana sumber daya dimobilisasi dan kekuasaan dibagi antara berbagai jenis stakeholder dalam rangka kolaborasi dalam masalah pembangunan tertentu. Perspektif saat ini melihat pemimpin bukan merupakan satu orang atau peran utama, tetapi sebagai aksi bersama karena berbagai stakeholder mengambil bagian dalam mencapai tujuan bersama (Fahmi, Prawira, Hudalah, \& Firman, 2015: 1-22).

Stakeholder dapat diartikan sebagai: (1) siapa pun yang memengaruhi atau terpengaruh oleh organisasi; (2) kelompok atau orang yang memiliki minat pada 
operasional dan keputusan organisasi, baik secara hukum, keuangan atau pernyataan moral, kontrak secara eksplisit maupun implisit; (3) pihak yang menyuplai sumber daya yang penting bagi organisasi; (4) pihak yang menempatkan sesuatu sebagai risiko; (5) pihak yang memiliki kekuasaan yang cukup untuk memengaruhi kinerja organisasi, baik yang menguntungkan maupun yang tidak menguntungkan (Jeffery, 2009:9).

Stakeholder dapat berupa individu maupun kelompok yang bisa berasal dari internal maupun dari eksternal. Stakeholder dapat berpengaruh atau terpengaruh oleh tindakan/tujuan/hasil dari sebuah program/proyek/aktivitas sebuah tim. Pengaruh ini dapat bersifat positif maupun negatif. Stakeholder yang terlibat dalam organisasi publik terbagi dalam tiga kelompok, yaitu: Pertama, stakeholder primer adalah mereka yang langsung berpengaruh/terpengaruh; kedua, stakeholder sekunder adalah mereka yang tidak langsung berpengaruh/terpengaruh; dan ketiga, stakeholder utama, dimana keberadaan mereka sangat penting bagi organisasi, yaitu mereka yang pasti berpengaruh/terpengaruh atas program/proyek/aktivitas sebuah tim (Rif'ati, 2016: 14).

Kondisi awal yang biasa terjadi pada proses kolaborasi ini, yaitu apakah pihak-pihak terkait memiliki visi yang sama, apakah pernah terjalin kerja sama sebelumnya dan apakah ada saling percaya. Hal ini perlu diperhatikan mengingat kekuatan, sumber daya dan pengetahuan yang dimiliki tidak setingkat (Tilano \& Suwitri, 2019:7). Huxham dan Hibbert dalam O'Flynn \& Wanna (2016: 46-48) menyebutkan bahwa terdapat lima tipe kolaborasi yang sukses, yaitu (1) mencapai outcome. Outcome ini dapat memiliki karakteristik berbeda bagi setiap pihak terkait; (2) tidak hanya hasil yang sukses namun proses kolaborasi yang sukses juga penting; (3) dapat mencapai tahapan tertentu; (4) memperoleh pengakuan dari orang lain; (5) mengakui kebanggaan pribadi ketika mendapatkan kerja sama. Kolaborasi dalam collaborative governance dapat dikatakan sukses apabila seluruh stakeholder terlibat; transparan dan bertanggung jawab; efektif dan adil; supremasi hukum terjamin; menjamin prioritas politik, sosial dan ekonomi didasarkan pada konsensus publik; dan memperhatikan yang lemah dalam pengambilan keputusan (Tilano \& Suwitri, 2019:9).

Pejabat publik merupakan pihak yang merepresentasikan aktor utama yang berperan dalam mencari dukungan, menginisiasi pertemuan, memfasilitasi dan memediasi, mendistribusikan pengetahuan, mendorong penggunaan teknologi dan melakukan advokasi pada masyakarat (Arrozaaq, 2016:9). Carmody dalam O'Flynn \& Wanna (2016:61) menyebutkan bahwa kepemimpinan efektif sangat penting dalam proses kolaborasi karena mengidentifikasikan tanggung jawab yang jelas dan bagaimana mengimplementasikan keputusan yang efektif. Oleh karena itu, peran pemimpin sangat menentukan dalam menentukan stakeholder terkait dan bagaimana memengaruhinya. Banyak metode analisis stakeholder yang dapat digunakan, salah satunya yaitu analisis net-map yang dilakukan untuk mengidentifikasi dan menganalisis stakeholder yang terlibat berdasarkan pengaruh dan kepentingan yang dimilikinya.

Berdasarkan analisis net-map, terdapat empat kelompok stakeholder, yaitu promoteurs, defenders, latens, dan apathetics. Stakeholders yang termasuk ke dalam promoteurs memiliki kepentingan besar, memiliki kekuatan yang cukup untuk membantu keberhasilan atau bahkan menggagalkan program (High Influence/High Interest). Stakeholders yang termasuk ke dalam defenders memiliki kepentingan pribadi, dapat memberikan dukungan dalam kelompok tertentu namun kurang memiliki kekuatan dalam memengaruhi (Low Influence/High Interest). Stakeholders yang termasuk ke dalam latens tidak memiliki kepentingan khusus dan tidak terlalu terlibat, tapi mereka memiliki kekuatan yang cukup untuk memengaruhi jika mereka tertarik (High Influence/Low Interest). Stakeholders yang termasuk ke dalam apathetics biasanya cenderung untuk tidak peduli 
karena mereka terlanjur menjadi anggota suatu kelompok atau karena jabatannya di dalam suatu kelompok. Stakeholder dalam kelompok ini tidak terlalu memiliki kemauan/dorongan dan hasrat, mereka juga mungkin tidak mengetahui adanya program/proyek/aktivitas (Low Influence/Low Interest) (Rif'ati, 2016: 14).

Strategi seorang pemimpin dalam memengaruhi tiap-tiap kelompok stakeholder tentu berbeda-beda. Strategi yang dilakukan untuk promotors adalah bagaimana agar para stakeholder ini dapat membuat program/proyek/aktivitas berjalan secara maksimal. Jika respon yang diberikan positif, maka stakeholder dalam kelompok ini perlu diperkokoh, diyakinkan terus dan diikutsertakan dalam pekerjaan yang mereka sukai, tetapi jika respon yang diberikan negatif/kurang mendukung, yakinkan mereka agar mereka tahu mengapa mereka harus terlibat dan sampaikan alasan-alasan untuk meyakinkan mereka dan upayakan semaksimal mungkin agar mereka terlibat. Strategi yang dapat dilakukan untuk defenders adalah dengan terus memberikan informasi tanpa perlu khawatir tentang apakah mereka terlibat atau tidak nantinya. Stakeholder dalam kelompok ini seringkali memberikan waktu dan kemampuannya saat program/proyek/aktivitas perlu bertahan.

Strategi yang dilakukan untuk latens adalah yakinkan mereka tentang pentingnya program/proyek/aktivitas yang dilakukan bagi mereka atau bagi kemaslahatan bersama. Lakukan pendekatan kepada mereka dengan melakukan kontak setiap saat, memberikan informasi secara jelas, tunjukkan bagaimana program/proyek/aktivitas yang dilakukan akan berdampak positif bagi hal yang menarik perhatian mereka. Strategi yang dilakukan untuk apathetics yaitu sebaiknya dibiarkan saja, tetapi mereka tetap harus diberikan informasi, bisa melalui surat edaran, pengumuman ataupun newsletter (Rif'ati, 2016: 17).

Keterikatan stakeholder yang efektif dan selaras secara strategis dapat memberikan keuntungan bagi organisasi, yaitu: (1) mengarah kepada pembangunan sosial yang lebih adil dan berkelanjutan dengan memberikan kesempatan kepada mereka yang berhak didengar untuk dipertimbangkan dalam proses pengambilan keputusan; (2) memungkinkan manajemen risiko dan reputasi yang lebih baik; (3) dapat menyatukan sumber daya untuk memecahkan masalah dan mencapai tujuan yang memerlukan kolaborasi antar organisasi; (4) memungkinkan pemahaman tentang lingkungan bisnis yang kompleks, termasuk pengembangan dan peluang strategis baru; (5) organisasi dapat belajar dari para stakeholder sehingga dapat menghasilkan peningkatan produk dan proses perbaikan; (6) meningkatkan peran pengambilan keputusan dan tindakan yang berdampak pada organisasi dan masyarakat dan (7) membangun kepercayaan antara organisasi dan stakeholder (Krick, Forstater, Monaghan, \& Sillanpaa, 2005:9).

Alur proses dalam mengikat stakeholder dapat digambarkan dalam tujuh tahapan, yaitu: (1) Tahap perencanaan; Dalam tahap ini, seorang pejabat publik harus dapat mengidentifikasi tujuan, masalah yang akan dipecahkan dan stakeholder mana yang menjadi prioritas (2) Tahap pemahaman; Dalam tahap ini, seorang pejabat publik harus dapat mengidentifikasi urgensi masalah, legitimasi kekuasaan dan minat yang dimiliki agar berdampak pada organisasi. Pahami keinginan dan kebutuhan stakeholder dan bagaimana hal itu dapat berkorelasi dengan keinginan dan kebutuhan organisasi. (3) penyelarasan dan persiapan internal; Dalam tahap ini, dedikasikan sumber daya dan waktu yang cukup untuk mengidentifikasi kemungkinan kesamaan yang dimiliki oleh organisasi dan stakeholder. Buatlah komitmen bersama. (4) Membangun kepercayaan; Sadari perbedaan antar stakeholder agar dapat berinteraksi dan beradaptasi sesuai dengan level kepercayaan yang dibutuhkan. (5) Konsultasi; Pejabat publik harus memiliki representasi yang sesuai bagi seluruh jenis stakeholder, tidak hanya untuk stakeholder yang mudah saja. Sediakan informasi yang kontekstual dan proposal yang merespon ekspektasi dan minat stakeholder 
secara langsung, tidak hanya informasi tentang tujuan dan aktivitas internal saja, termasuk kemungkinan terjadinya trade-off antara ekspektasi, kebutuhan dan tujuan yang akan membantu dalam membangun kepercayaan dan kerja sama. Mekanisme konsultasi bisa berupa wawancara, workshop, diskusi (FGD), rapat, survei, alat yang partisipatif, dan panel stakeholder. Sesuaikan mekanisme yang ada dengan jenis stakeholder. (6) Respon dan implementasi; Pejabat publik harus menentukan serangkaian aksi bagi setiap masalah yang telah disepakati untuk dipecahkan. Dengan memahami reaksi stakeholder, pejabat publik akan dapat membuat dan mengembangkan proposal aksi yang lebih sukses. (7) Monitor, Evaluasi dan Dokumentasi. Manajemen pengetahuan dapat membantu dalam proses pengumpulan informasi dan berbagi apa yang sudah dipelajari. Laporan progress harus disampaikan kepada stakeholder terkait dengan penyesuaian pada bentuk laporan dan bahasa yang digunakan (Jeffery, 2009:9).

Berkaitan dengan evaluasi, setelah proses mobilisasi stakeholder dilakukan, pemimpin perubahan perlu melakukan evaluasi untuk mengetahui sejauh mana anggota organisasi melakukan rutinitas, praktik atau perilaku yang ditargetkan dalam perencanaan. Pemimpin memiliki peran strategis dalam mengevaluasi dan memastikan setiap anggota organisasi menjalankan rutinitas baru. Sebelum proyek perubahan dilembagakan, pemimpin perubahan seringkali mundur untuk menilai proses dan prosedur baru yang telah diterapkan dan bagaimana dampaknya terhadap kinerja organisasi (Rif'ati, 2016: 14).

\section{Penelitian Sebelumnya}

Pada tahun 2010 Battilana, dkk. melakukan penelitian mengenai kompetensi kepemimpinan dalam aktivitas yang berkaitan dengan penerapan perencanaan organisasi. Aktivitas tersebut meliputi komunikasi, mobilisasi, dan evaluasi. Penelitian menunjukkan bahwa terdapat perbedaan perilaku antara pemimpin yang berorientasi pada tugas dan pemimpin yang berorientasi pada manusia dalam hal implementasi perubahan dalam organisasi. Pemimpin yang berorientasi pada tugas lebih berfokus pada aktivitas mobilisasi dan evaluasi sedangkan pemimpin yang berorientasi pada manusia lebih berfokus pada komunikasi atas kebutuhan perubahan organisasi (Battilana et al., 2010: 433).

Penelitian tentang kepemimpinan dan perencanaan juga dilakukan oleh Fahmi dkk di tahun 2015. Penelitian menunjukkan bahwa faktor-faktor kepemimpinan yang berkontribusi terhadap proses perencanaan diantaranya yaitu kemampuan mengatasi konflik, penyusunan visi, penataan pengetahuan dan sumber daya, menumbuhkan kepercayaan, membuat stakeholder untuk bekerja sama/berkolaborasi dalam melaksanakan tugas dan membangun kerangka belajar (Fahmi et al., 2015: 1-22).

Fairus dan Andri pada tahun 2014 meneliti tentang perencanaan kinerja tahunan yang salah satunya dapat dilakukan melalui penilaian evaluasi LAKIP tahun sebelumnya ditinjau dari masukan (input); keluaran (output); hasil (outcome); manfaat (benefit) dan dampak (impact) yang tersaji dalam LAKIP itu sendiri. Hasil penelitian menunjukkan bahwa proses perencanaan kinerja tahunan melalui evaluasi LAKIP terlaksana dengan baik walaupun mengalami beberapa hambatan seperti keterbatasan SDM, kurang matangnya penetapan rencana dan belum optimalnya fungsi koordinasi, integrasi, sinergi, dan sinkronisasi antar SKPD (Fairus \& Andri, 2014: 104).

Sistem penilaian kinerja di Indonesia yang menggunakan LAKIP sebagai dasar penilaian kinerja juga diteliti oleh Akbar, dkk. pada tahun 2015. Hasil penelitian menunjukkan bahwa masih terdapat instansi pemerintah yang tidak menyusun LAKIP dan/atau menyusun LAKIP namun tidak disusun secara baik dan benar. LAKIP disusun dengan bantuan konsultan seperti pihak universitas. Kurangnya motivasi, komitmen 
pimpinan dan kurangnya kemampuan pegawai menjadi salah satu penyebabnya. Selain itu, adanya intervensi politik juga menjadi salah satu faktor penghambat (Akbar, Pilcher, \& Perrin, 2015: 24).

Penelitian mengenai perencanaan dan kepemimpinan juga dilakukan oleh Johnson pada tahun 2018 yang menyoroti tentang pemimpin yang dapat membantu para perencana menemukan gaya kepemimpinan yang sesuai dengan zona nyaman mereka. Hasil penelitian menunjukkan bahwa definisi pemimpin saat ini mirip dengan apa yang dilakukan oleh para perencana. Perencana dapat menjadi pemimpin yang efektif dengan cara menemukan zona nyaman mereka (Johnson, 2018: 155).

Enadarlita pada tahun 2019 meneliti mengenai pengaruh kompetensi manajerial dan gaya kepemimpinan terhadap keinovatifan pejabat administrator. Hasilnya mengungkapkan bahwa kompetensi manajerial dan gaya kepemimpinan berpengaruh secara positif dan signifikan terhadap tingkat inovasi seorang pejabat administrator. Kompetensi manajerial yang perlu dimiliki oleh seorang pemimpin dalam mendukung tingkat inovasi antara lain yaitu (1) kompetensi berfikir (fleksibel berfikir, kemampuan menyusun rencana, berfikir analitis, berfikir konseptual) dan (2) mengelola tugas (pencarian informasi, komunikasi lisan, komunikasi tertulis, berorientasi pada pelayanan) serta gaya kepemimpinan transformasional yang mendukung tingkat inovasi (Enadarlita, 2019: 169-178).

Penelitian yang dilakukan oleh penulis memiliki perbedaan dengan penelitian yang disampaikan di atas. Penelitian ini lebih berfokus pada pengaruh kemampuan menyusun perencanaan dan mobilisasi stakeholder yang dimiliki oleh pejabat publik terhadap pencapaian target kinerja yang telah ditetapkan.

\section{HASIL DAN PEMBAHASAN}

Pelatihan kepemimpinan yang terdiri atas PKN Tk. II, Diklatpim Tk. III dan Diklatpim Tk. IV diselenggarakan dengan tujuan untuk mengembangkan kompetensi peserta dalam rangka memenuhi standar kompetensi manajerial di tiap jenjang jabatan. Salah satu kompetensi manajerial yang disyaratkan, yaitu kemampuan menyusun perencanaan dan kemampuan memobilisasi stakeholder.

Jumlah pejabat publik yang menjadi sampel penelitian adalah 280 orang, yang terdiri atas 80 orang peserta Diklatpim Tk. IV, 78 orang peserta Diklatpim Tk. III, dan 122 orang peserta PKN Tk. II yang telah mengikuti pelatihan kepemimpinan yang diselenggarakan oleh Puslatbang PKASN LAN pada tahun 2019. Berdasarkan hasil pengolahan data, rata-rata kemampuan menyusun perencanaan pejabat publik tersebut adalah sebesar 83,14 ; rata-rata kemampuan memobilisasi stakeholder mencapai 86,15 ; dan rata-rata pencapaian target kinerja mencapai 86,57. Hal ini menunjukkan bahwa pejabat publik di Indonesia memiliki standar kompetensi manajerial yang memuaskan.

Sebelum melakukan analisis regresi linier berganda, terlebih dahulu dilakukan berbagai pengujian asumsi klasik. Pertama, uji normalitas untuk mengetahui apakah variabel pengganggu atau residual mempunyai distribusi normal dalam model regresi yang digunakan. Uji t dan F mengasumsikan nilai residual mengikuti distribusi normal. Apabila terjadi pelanggaran asumsi ini, maka uji statistik menjadi tidak valid untuk jumlah sampel kecil. Analisis grafik dan uji statistik digunakan untuk mendeteksi apakah residual memiliki distribusi normal atau tidak. Dengan melihat penyebaran data/titik pada sumbu diagonal dari grafik atau dengan melihat histogram dari residualnya maka normalitas dapat terlihat. Model regresi dikatakan memenuhi asumsi normalitas apabila data menyebar di sekitar garis diagonal atau grafik histogramnya (Janie, 2012: 35-38). Berikut ini grafik dari uji normalitas: 
Histogram

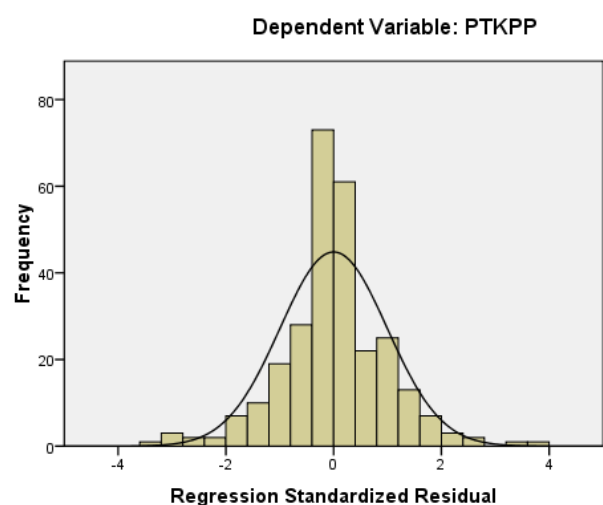

Normal P-P Plot of Regression Standardized Residual

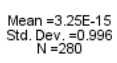

Dependent Variable: PTKPP

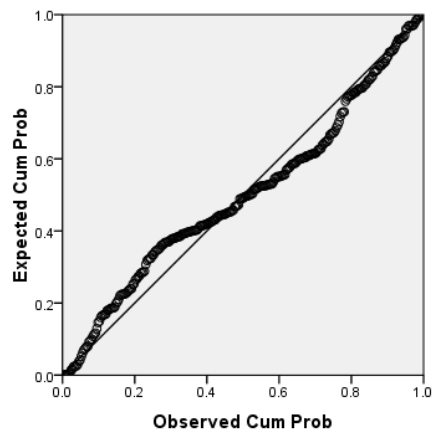

Gambar 1.

Hasil Uji Normalitas (Sumber: diolah)

Dengan melihat tampilan grafik histogram yang agak menceng ke kiri, dapat disimpulkan bahwa grafik histogram memberikan pola distribusi yang tidak normal, sedangkan pada grafik normal plot terlihat titik-titik menyebar jauh di sekitar garis diagonal, serta penyebarannya tidak mengikuti arah garis diagonal. Kedua grafik pada uji normalitas ini menunjukkan bahwa model regresi tidak layak digunakan karena tidak memenuhi asumsi normalitas. Hasil uji normalitas residual dengan grafik dapat membingungkan apabila tidak dilakukan dengan teliti. Secara kasatmata terlihat normal tetapi secara statistik dapat berarti sebaliknya. Oleh karenanya, uji normalitas ini dilengkapi pula dengan uji Kolmogorov Smirnov. Hasil penelitian ini menunjukkan besarnya nilai Kolmogorov Smirnov adalah 0,866 dengan tingkat signifikansi 0,441 (di atas 0,01) yang berarti tidak signifikan. Hal ini berarti residual terdistribusi secara normal yang artinya model regresi linier berganda memenuhi asumsi normalitas.

Kedua, uji heteroskedastisitas. Uji heteroskedastisitas dilakukan untuk menguji apakah model regresi yang digunakan memiliki varian yang sama atau berbeda. Uji ini dilakukan melalui dua cara, yaitu melalui metode grafik dan metode statistik. Metode grafik dilakukan dengan melihat grafik plot antara nilai prediksi variabel dependen dengan residualnya. Sementara metode statistik dilakukan dengan Uji Glejser. Uji Glejser ini dilakukan dengan meregresikan nilai absolute residual (AbsUi) terhadap variabel independen lainnya. Kriteria pengujian adalah apabila $\beta$ signifikan, maka mengindikasikan terdapat heteroskedastisitas dalam model regresi yang digunakan (Janie, 2012: 24-29). Gambar 2 merupakan hasil uji heteroskedastisitas.

Grafik scatterplots pada gambar 2 menunjukkan bahwa titik-titik tidak menyebar secara acak. Hal ini mengindikasikan adanya heteroskedastisitas pada model regresi. Untuk memastikan ada tidaknya heteroskedastisitas pada model, diperlukan Uji Glejser sebagaimana pada tabel 1 .

Hasil uji Glejser pada tabel 1 menunjukkan bahwa variabel KMP dan KMS memiliki nilai signifikansi 0,616 dan 0,463, keduanya di atas 0,01. Hal ini menunjukkan bahwa tidak terdapat heteroskedastisitas dalam model regeresi ini. Artinya semua variabel independen yang terdapat dalam model ini memiliki sebaran varian yang sama/homogen. 
Scatterplot

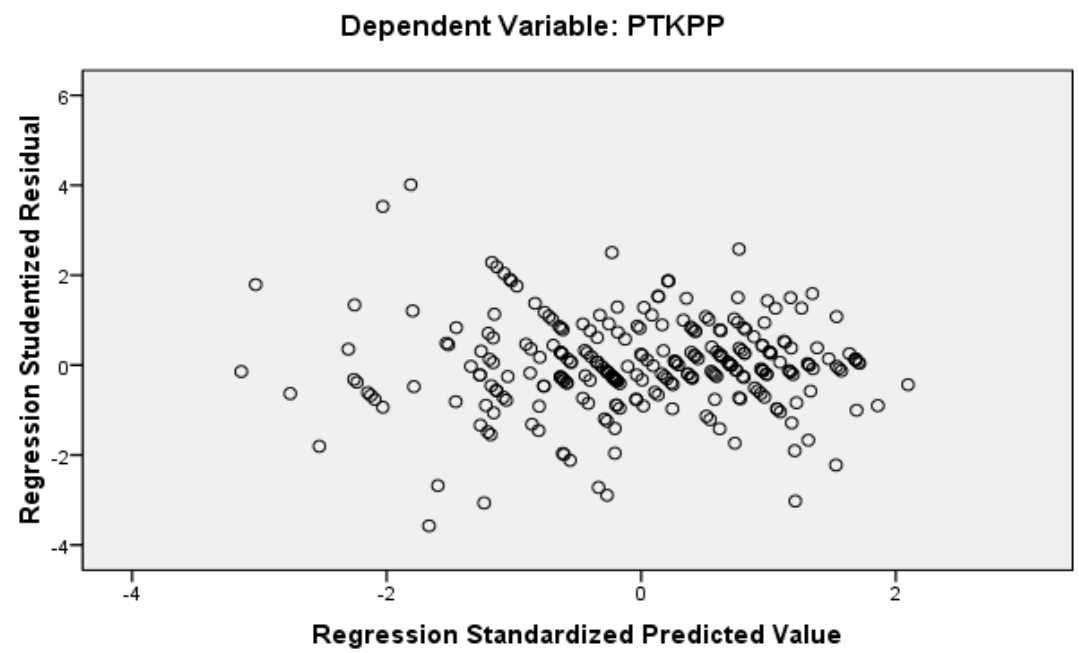

Gambar 2.

Hasil Uji Heteroskedastisitas (Sumber: diolah)

Tabel 1.

Uji Glejser

\section{Coefficients $^{\mathrm{a}}$}

\begin{tabular}{|c|c|c|c|c|c|c|}
\hline \multirow[b]{2}{*}{ Model } & & \multicolumn{2}{|c|}{ Unstandardized Coefficients } & \multicolumn{2}{|c|}{$\begin{array}{l}\text { Standardized } \\
\text { Coefficients }\end{array}$} & \multirow[b]{2}{*}{ Sig. } \\
\hline & & $\mathrm{B}$ & Std. Error & Beta & $\mathrm{t}$ & \\
\hline \multirow[t]{3}{*}{1} & (Constant) & 2.555 & 3.333 & & .767 & .446 \\
\hline & KMP & .023 & .046 & .086 & .504 & .616 \\
\hline & KMS & -.040 & .054 & -.126 & -.738 & .463 \\
\hline
\end{tabular}

a. Dependent Variable: AbsUi

Sumber: diolah

Ketiga, uji multikolinieritas. Uji multikolinieritas bertujuan untuk menguji ada tidaknya korelasi yang tinggi atau sempurna antar variabel independen dalam model. Apabila antar variabel independen terjadi multikolinieritas sempurna, maka koefisien regresi variabel independen tidak dapat ditentukan dan nilai standard error independen menjadi tak terhingga. Apabila multikolinieritas antar variabel independen tinggi, koefisien regresi variabel independent dapat ditentukan, tetapi memiliki nilai standar error tinggi. Hal ini menunjukkan bahwa nilai koefisien regresi tidak dapat diestimasi dengan tepat (Janie, 2012: 19-23).

Berdasarkan uji multikolinieritas, terlihat bahwa nilai $\mathrm{R}^{2}$ cukup tinggi, yaitu sebesar $87,8 \%$, sementara variabel independent memiliki nilai t statistik yang signifikan pada $\alpha=$ $5 \%$. Oleh karena $\mathrm{R}^{2}$ tinggi dan variabel independennya signifikan, maka tidak ada indikasi terjadi multikolinieritas antarvariabel independen seperti terlihat pada tabel 2. 
Tabel 2.

Model Summary ${ }^{\mathrm{b}}$

\begin{tabular}{|c|c|c|c|c|}
\hline Model & $\mathrm{R}$ & R Square & Adjusted R Square & $\begin{array}{l}\text { Std. Error of the } \\
\text { Estimate }\end{array}$ \\
\hline 1 & $.937^{\mathrm{a}}$ & .878 & .877 & 1.82271 \\
\hline
\end{tabular}

a. Predictors: (Constant), KMS, KMP

b. Dependent Variable: PTKPP

Sumber: diolah

Berdasarkan ketiga uji asumsi klasik yang telah dilakukan, dapat disimpulkan bahwa model regresi linier berganda tersebut dapat digunakan. Hal ini dikuatkan dengan nilai adjusted $R^{2}$ sebesar 0,877 pada output SPSS model summary. Hal ini menunjukkan bahwa $87,7 \%$ variasi pencapaian target kinerja pejabat publik di Indonesia dapat dijelaskan oleh kemampuan menyusun perencanaan dan kemampuan memobilisasi stakeholder. Sementara $12,3 \%$ sisanya dijelaskan oleh sebab-sebab lain di luar model. Standard error of the estimate (SEE) sebesar 1,82271 menunjukkan makin kecil nilai SEE akan membuat model regresi semakin tepat dalam memprediksi variabel dependen.

Koefisien regresi dapat digunakan untuk mengetahui ada tidaknya pengaruh dari variabel Kemampuan Menyusun Perencanaan dan Kemampuan Memobilisasi Stakeholder terhadap Pencapaian Target Kinerja Pejabat Publik. Berdasarkan Tabel 3, hasil perhitungan menunjukkan bahwa nilai $\mathrm{F}$ hitung sebesar 996,672 dengan probabilitas 0,000. Oleh karena probabilitas jauh lebih kecil dari 0,05 dapat disimpulkan bahwa koefisien regresi untuk variabel Kemampuan Menyusun Perencanaan dan variabel Kegiatan Memobilisasi Stakeholder tidak sama dengan nol. Dengan kata lain, kedua variabel independen ini secara simultan berpengaruh terhadap variabel dependen. Dengan demikian hipotesis yang ditetapkan dapat diterima.

Tabel 3.

Tabel ANOVA (F Test)

\begin{tabular}{|c|c|c|c|c|c|c|}
\hline Model & & Sum of Squares & $\mathrm{df}$ & Mean Square & $\mathrm{F}$ & Sig. \\
\hline \multirow[t]{3}{*}{1} & Regression & 6622.440 & 2 & 3311.220 & 996.672 & $.000^{\mathrm{a}}$ \\
\hline & Residual & 920.271 & 277 & 3.322 & & \\
\hline & Total & 7542.711 & 279 & & & \\
\hline
\end{tabular}

a. Predictors: (Constant), KMS, KMP

b. Dependent Variable: PTKPP

Sumber: diolah

Selanjutnya, untuk menginterpretasikan koefisien parameter variabel independen dapat menggunakan unstandardized coefficients seperti yang tercantum pada Hasil Regresi Linier Berganda di tabel 4. 
Tabel 4.

Coefficients $^{\mathrm{a}}$

Hasil Regresi Linier Berganda

\begin{tabular}{|c|c|c|c|c|c|c|}
\hline \multirow{2}{*}{\multicolumn{2}{|c|}{ Model }} & \multicolumn{2}{|c|}{ Unstandardized Coefficients } & \multirow{2}{*}{$\begin{array}{c}\text { Standardized } \\
\text { Coefficients }\end{array}$} & \multirow[b]{2}{*}{$\mathrm{t}$} & \multirow[b]{2}{*}{ Sig. } \\
\hline & & $\mathrm{B}$ & Std. Error & & & \\
\hline \multirow[t]{3}{*}{1} & (Constant) & 2.968 & 2.054 & & 1.445 & .150 \\
\hline & KMP & .092 & .033 & .082 & 2.804 & .005 \\
\hline & KMS & .882 & .029 & .878 & 29.920 & .000 \\
\hline
\end{tabular}

a. Dependent Variable: PTKPP

Sumber: Diolah

Berdasarkan kolom Unstandardized Beta Coefficients, kedua variabel independent yang terdapat dalam model signifikan pada $\alpha=5 \%$, hal ini terlihat dari probabilitas signifikansi sebesar 0,005 untuk variabel KMP dan 0,000 untuk variabel KMS. Jadi dapat disimpulkan bahwa variabel PTKPP dipengaruhi oleh variabel KMP dan variabel KMS, dengan koefisien persamaan matematis sebagai berikut.

$$
\mathrm{PTKPP}=3,559+0,096 \mathrm{KMP}+0,875 \mathrm{KMS}
$$

Persamaan di atas menunjukkan bahwa koefisien konstanta bernilai positif $(3,559)$. Hal ini menyatakan bahwa dengan mengasumsikan variabel Kemampuan Menyusun Perencanaan (KMP) dan variabel Kemampuan Memobilisasi Stakeholder (KMS) tetap, maka Pencapaian Target Kinerja Pejabat Publik (PTKPP) mengalami peningkatan. Koefisien regresi Kemampuan Menyusun Perencanaan (KMP) bernilai positif menyatakan bahwa dengan mengasumsikan variabel Kegiatan Memobilisasi Stakeholder (KMS) tetap, dan apabila Kemampuan Menyusun Perencanaan (KMP) mengalami peningkatan, maka Pencapaian Target Kinerja Pejabat Publik (PTKPP) juga mengalami peningkatan. Koefisien regresi Kegiatan Memobilisasi Stakeholder (KMS) bernilai positif menyatakan bahwa dengan mengasumsikan variabel Kemampuan Menyusun Perencanaan (KMP) tetap, dan apabila Kegiatan Memobilisasi Stakeholder (KMS) mengalami peningkatan, Pencapaian Target Kinerja Pejabat Publik (PTKPP) juga mengalami peningkatan.

Hasil penelitian menunjukkan bahwa Kemampuan Menyusun Perencanaan dan Kemampuan Memobilisasi Stakeholder berpengaruh secara positif dan signifikan terhadap pencapaian tujuan/target organisasi. Teori kepemimpinan mengungkapkan bahwa seorang pemimpin harus mampu mengartikulasi visi, mewujudkan nilai, dan menciptakan lingkungan agar tercapainya tujuan organisasi. Kepemimpinan diartikan sebagai langkah/usaha membuat perubahan dalam organisasi dengan menyusun visi, misi dan strategi untuk membuat perubahan yang dibutuhkan, mengkomunikasikan dan menjelaskan visi, serta memotivasi dan memberi inspirasi kepada orang lain untuk mencapai visi tersebut. Pengertian tersebut dan didukung oleh hasil penelitian, maka semakin memperjelas peran penting seorang pemimpin dalam menyusun perencanaan, mengelola sumber daya organisasi, termasuk didalamnya memobilisasi stakeholder, untuk menghasilkan kinerja sesuai dengan tujuan yang telah ditargetkan. Kemampuan menyusun perencanaan dan memobilisasi stakeholder didukung oleh karakteristik pemimpin yang diungkapkan oleh Northouse (2016) yang menyatakan bahwa seorang pemimpin harus memiliki tanggung 
jawab, semangat, gigih, berani mengambil resiko, memiliki orisinalitas dalam menyelesaikan masalah, percaya diri, dapat memengaruhi orang lain, dan dapat menyusun sistem interaksi sosial.

Hasil penelitian ini juga menguatkan hasil penelitian yang dilakukan oleh Fahmi, dkk (2015) yang menyatakan bahwa salah satu faktor kepemimpinan yang berkontribusi terhadap pelaksanaan tugas, dalam hal ini yaitu pencapaian kinerja, adalah penyusunan visi dan membuat kerjasama atau kolaborasi dengan stakeholder. Hal ini juga memperkuat teori kepemimpinan dengan pendekatan kepribadian yang menyatakan bahwa pemimpin yang memiliki kemampuan sosial dalam membangun hubungan sosial akan mudah diterima oleh lingkungan stakeholder yang dapat mendukung upaya pemimpin dalam mencapai tujuan yang telah ditetapkan. Dalam konteks kepemimpinan, seorang pemimpin atau pejabat publik dapat memobilisasi sumber daya institusional, politis, psikologis, dan sumbersumber lainnya dan menciptakan lingkungan guna mencapai tujuan. Tujuan yang dimaksud adalah kinerja organisasi. Hasil penelitian ini pun mendukung pernyataan bahwa para pejabat publik yang dapat memobilisasi sumber daya terkait, termasuk stakeholder, akan mendukung dalam pencapaian target kinerja.

Hasil penelitian ini juga sesuai dengan yang diungkapkan oleh Battilana et.al (2010) dan Mumford, Todd, Higgs, \& McIntosh (2016), yaitu bahwa keterampilan menyusun perencanaan dan bagaimana seorang pemimpin menghadapi perubahan yang terjadi sangat mendukung dalam keberhasilan pencapaian target kinerja organisasi. Hasil penelitian menunjukkan bahwa ketika seorang pemimpin dapat menyusun perencanaan dengan baik dan dapat menghadapi perubahan dalam perencanaan serta dapat memobilisasi stakeholder terkait, maka target kinerja secara signifikan akan tercapai.

Kepemimpinan merupakan proses yang melibatkan pengaruh dan kerja sama dalam upaya mencapai tujuan bersama, dalam hal ini yaitu target kinerja yang telah ditetapkan. Seorang pemimpin harus berani mengambil keputusan, baik internal maupun eksternal, dimana salah satunya melibatkan keputusan tentang menyusun perencanaan/strategi, membentuk tim efektif, menentukan stakeholder dan memobilisasinya. Sebagai seorang pejabat publik yang memiliki area yang luas, ia harus dapat menghadapi lingkungan yang berubah/dinamis, baik secara internal maupun eksternal, termasuk dalam menghadapi berbagai stakeholder. Para pejabat publik yang telah mengikuti pelatihan kepemimpinan diharapkan memiliki kompetensi manajerial, salah satunya yaitu kemampuan menyusun perencanaan dan kemampuan memobilisasi stakeholder, yang dibutuhkan untuk mencapai target kinerja yang telah ditetapkan.

\section{E. PENUTUP}

Penelitian ini bertujuan untuk mengetahui pengaruh dari kemampuan menyusun perencanaan dan kemampuan memobilisasi stakeholder terhadap pencapaian target kinerja pejabat publik. Melalui analisis regresi linier berganda, dapat dilihat hubungan setiap variabel independen terhadap variabel dependen. Variabel kemampuan menyusun perencanaan memiliki pengaruh positif terhadap pencapaian target kinerja pejabat publik. Secara statistik, pengaruh dari kemampuan menyusun perencanaan terhadap pencapaian target kinerja pejabat publik adalah signifikan. Begitu pula dengan variabel kemampuan memobilisasi stakeholder yang memiliki pengaruh positif terhadap pencapaian target kinerja pejabat publik. Secara statistik, pengaruh dari kemampuan memobilisasi stakeholder terhadap pencapaian target kinerja pejabat publik adalah signifikan. Bahkan secara bersama-sama antara kemampuan menyusun perencanaan dan kemampuan 
memobilisasi stakeholder berpengaruh secara signifikan terhadap pencapaian target kinerja pejabat publik.

Dalam teori kepemimpinan, kemampuan menyusun perencanaan dan kemampuan memobilisasi stakeholder dibutuhkan untuk keberhasilan organisasi. Manajemen yang kuat saja hanya akan menciptakan birokrasi tanpa tujuan, akan tetapi kepemimpinan yang kuat saja juga hanya akan menghasilkan perubahan dengan cara yang kurang praktis. Sehingga dibutuhkan kolaborasi dalam implementasinya. Seorang pemimpin yang dapat menyusun rencana strategis dan dapat memobilisasi stakeholder yang tepat berdasarkan analisis diharapkan akan mampu menghasilkan kinerja organisasi sesuai dengan target/tujuan yang telah ditetapkan.

Berkaitan dengan hasil dari model regresi linier berganda yang digunakan, disimpulkan bahwa kemampuan menyusun perencanaan dan memobilisasi stakeholder berpengaruh secara positif dan signifikan terhadap pencapaian target kinerja pejabat publik. Sangat dimungkinkan bahwa model regresi linier berganda yang digunakan belum memasukkan variabel-variabel lainnya. Sehubungan dengan hal tersebut, diperlukan penelitian lanjutan untuk mengukur dan memodelkan berbagai aspek yang berkaitan dengan pencapaian target kinerja pejabat publik selain variabel yang digunakan dalam penelitian ini seperti dukungan sumber daya manusia, besaran anggaran, dukungan sarana dan prasarana, dan aspek-aspek lainnya.

\section{DAFTAR PUSTAKA}

Akbar, Rusdi; Pilcher, Robyn Ann; Perrin, B. (2015). Implementing Performance Measurement Systems: Indonesian Local Government Under Pressure. Qualitative Research in Accounting \& Management, Vol. 12(1), 3-33.

Ansell, C., \& Gash, A. (2008). Collaborative Governance in Theory and Practice. Journal of Public Administration Research and Theory, 18(4), 543-571. https://doi.org/10.1093/jopart/mum032

Arrozaaq, D. L. C. (2016). Collaborattive Governance (Studi Tentang Kolaborasi Antar Stakeholders Dalam Pengembangan Kawasan Minapolitan di Kabupaten Sidoarjo). Kebijakan Dan Manajemen Publik, 3, 1-13. Retrieved from http://repository.unair.ac.id/67685/

Asmoko, H. (2014). Pengembangan Kepemimpinan Transformasional dan Peran Diklat Kepemimpinan Pola Baru. Balai Diklat Kepemimpinan Magelang, 1, 1-9.

Battilana, J., Gilmartin, M., Sengul, M., Pache, A. C., \& Alexander, J. A. (2010). Leadership Competencies For Implementing Planned Organizational Change. Leadership Quarterly, 21(3), 422-438. https://doi.org/10.1016/j.leaqua.2010.03.007

Boyatzis, R., \& McKee, A. (2006). Resonant Leadership Renewing Yourself and Conecting with Others Through Mindfulness, Hope, and Compassion. Hardvard Business School Press.

Emerson, K., Nabatchi, T., \& Balogh, S. (2012). An Integrative Framework for Collaborative Governance. Journal of Public Administration Research and Theory, 22(1), 1-29. https://doi.org/10.1093/jopart/mur011

Enadarlita. (2019). Pengaruh Kompetensi Manajerial dan Gaya Kepemimpinan terhadap Keinovatifan Pejabat Administrator di Provinsi Jambi. Jurnal Manajemen, Kepemimpinan dan Supervisi Pendidikan, 4(2).

Fahmi, F. Z., Prawira, M. I., Hudalah, D., \& Firman, T. (2015). Leadership and collaborative planning: The Case of Surakarta, Indonesia. Planning Theory, 15(3), 1-22. https://doi.org/10.1177/1473095215584655 
Fairus, M., \& Andri, S. (2014). Perencanaan Kinerja Tahunan Melalui Penilaian Evaluasi LAKIP. Jurnal Kebijakan Publik, 5(1), 1-117.

Farizal, Rachman, A., \& Al Rasyid, H. (2014). Model Peramalan Konsumsi Bahan Bakar Jenis Premium di Indonesia dengan Regresi Linier Berganda. Jurnal Ilmiah Teknik Industri, 13(2), 166-176.

Febrian, R. A. (2016). Collaborative Governance dalam Pembangunan Kawasan Perdesaan. Wedana, 11(1), 200-208. $\quad$ Retrieved from http://journal.uir.ac.id/index.php/wedana/article/view/1824 diakses pada tanggal 5 April 2019 pukul 02:55 WIB

Harmawan, B. N., Wasiati, I., \& Rohman, H. (2017). Collaborative Governance Dalam Program Pengembangan Nilai Budaya Daerah Melalui Banyuwangi Ethno Carnival ( Collaborative Governance in Local Culture Values Development Program Through

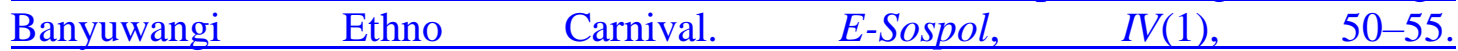
https://doi.org/10.1002//no.10208

Hartley, J. (2018). Ten Propositions about Public Leadership. International Journal of Public Leadership, 14(4), 202-217. https://doi.org/10.1108/ijpl-09-2018-0048

Janie, D. (2012). Statistik Deskriptif \& Regresilinier Berganda dengan SPSS. Semarang: Semarang University Press.

Jeffery, N. (2009). Stakeholder Engagement : A Road Map to Meaningful Engagement.

Johnson, B. J. (2018). Planners as Leaders: Finding their Comfort Zone. International Journal of Public Leadership, 14(3), 155-178. https://doi.org/10.1108/ijpl-04-20180022

Krick, T., Forstater, M., Monaghan, P., \& Sillanpaa, M. (2005). The Stakeholder Engagement Manual. In Society. Canada: Stakeholder Research Associates Canada Inc.

Margulis, A. R. (2002). Be In Charge: A Leadership Manual (1st ed). New York: Academic Press.

Mumford, M. D., Todd, E. M., Higgs, C., \& McIntosh, T. (2016). Cognitive Skills and Leadership Performance: The Nine Critical Skills. Leadership Quarterly, 28(1), 1-16. https://doi.org/10.1016/j.leaqua.2016.10.012

Northouse, P. G. (2016). Leadership: Theory and Practice (7th Ed.). California: SAGE Publications, Inc.

Nugroho, R. (2008). Public Policy: Teori Kebijakan, Analisis Kebijakan, Proses Kebijakan, Perumusan, Implementasi, Evaluasi, Revisi Risk Management dalam Kebijakan Publik sebagai The Fifth Estate, Metode Penelitian Kebijakan. Jakarta: Elex Media Komputindo.

Nurhidayah. (2018). Evaluasi Kegiatan Partisipasi Masyarakat pada Program Penataan Lingkungan Berbasis Komunitas. Arcade Jurnal Arsitektur, 2(1), 12-18.

O’Flynn, J., \& Wanna, J. (2016). Collaborative Governance. In Handbook on Theories of Governance. https://doi.org/10.5840/iabsproc1993412

Peramesti, Y., \& Kusmana, D. (2018). Kepemimpinan Ideal pada Era Generasi Milenial. Jurnal Manajemen Pemerintahan, 10(Maret), 73-78.

Rif'ati, E. F. (2016). Strategi Mengelola Program Organisasi dengan Dukungan Seluruh Stakeholder Terkait Dengan Pendekatan Net Mapping pada Penyusunan Proyek Perubahan dalam Diklat PIM IV Pola Baru. Forum Manajemen, 06(2).

Sari, D. (2017). Strategi Mobilisasi Gerakan Masyarakat dalam Penutupan Industri Pengelolaan Limbah B3 di Desa Lakardowo Kabupaten Mojokerto. Jurnal Politik Indonesia, 2(1), 127-134.

Squires, V. (2018). Book Review: Northouse , P . G . ( 2016 ). Leadership: Theory and 
Practice (7th ed). Thousand Oaks, CA: Sage. Canadian Journal of Educational Administration and Policy, 91-94.

Syukur, H. (2014). Diklat Kepemimpinan Pola Baru, Apa, Bagaimana Implementasinya dan Tantangannya. Forum Diklat, 04(2), 1-10.

Tilano, F., \& Suwitri, S. (2019). Collaborative Governance dalam Upaya Keselamatan Lalu Lintas dan Angkutan Jalan di Kota Semarang. 1, 1-18.

Yudiatmaja, F. (2013). Kepemimpinan: Konsep, Teori, dan Karakternya. Media Komunikasi FIS, 12(Agustus), 29-38. https://doi.org/10.6007/ijarbss/v3-i10/295

Yukl, G. (2009). Leadership in Organitation (Fifth Edit). New Jersey: Prentice Hall, Inc. 